\title{
PENERAPAN PEMBELAJARAN KOOPERATIF MODEL TIPE STAD PADA PEMBELAJARAN EKONOMI DI KELAS XI MA USB FILIAL BATAM
}

\author{
LISMAWATY MUNTHE \\ MA USB FILIAL MAN BATAM \\ E-Mail : lismawatimunthe@gmail.com
}

\begin{abstract}
ABSTRAK
Tujuan penelitian ini adalah untuk meningkatkan hasil belajar siswa dengan menggunakan model pembelajaran kooperatif tipe STAD pada mata pelajaran Ekonomi serta meningkatkan aktivitas belajar dan psikomotorik pada siswa MA USB FIIAL MAN Batam Tahun Pelajaran 2018/2019. Metode penelitian yang digunakan adalah penelitian tindakan kelas dengan 2 siklus. Siklus 1 menjelaskan sub konsep tentang ilmu ekonomi sedangkan pada siklus 2 menjelaskan sumber daya yang ada melalui pilihan - pilihan kegiatan produksi,konsumsi dan distribusi. Adapun hasil penelitian ini menunjukan peningkatkan minat, perhatian serta motivasi belajar siswa kelas XI MA USB FILIAL BATAM pada mata Pelajaran Ekonomi dengan menggunakan model yang bervariasi, menggunakan alat peraga dan memeberikan kesempatan kepada siswa untuk bertanya tentang materi yang belum dipahami. Sehingga penggunaan model pembelajaran kooperatif pantas dipertimbangkan untuk digunakan guru khusus di XI MA USB FILIAL Batam Kota pada mata pelajaran EKONOMI model pembelajaran kooperatif memeberikan dampak yang positif terhadap peningkatan minat, perhatian serta motivasi belajar siswa.
\end{abstract}

Kata Kunci: Pembelajaran Koopertif, STAD, Ekonomi, MA USB FILIAL

\section{PENDAHULUAN}

Hal yang paling disorot pada peningkatan kualitas pendidikan salah satu diantaranya yang paling mendasar adalah hasil uji kompetensi lulusan suatu sekolah yang tentunya diawali dari hasil uji kompetensi siswa pada jenjang dibawahnya. . Hasil belajar siswa menjadi hal yang ikut menentukan dalam keberhasilan guru dalam kegiatan belajar dan mengajarnya, dimana cara belajar siswa sebagai bagian yang tak terpisahkan dalam pencapaian itu. Oleh karena itu perlu dicari berbagai kiat dalam meningkatkan hasil belajar siswa.Belajar merupakan proses dalam diri individu yang berinteraksi dengan lingkungan untuk mendapatkan perubahan dalam perilakunya. Belajar adalah aktivitas mental/psikis yang berlangsung dalam interaksi aktif dengan lingkungan yang menghasilkan perubahanperubahan dalam pengetahuan. ketrampilan dan sikap (Winkel : 1999).

Proses belajar dapat melibatkan aspek kognitif, afektif dan psikomotorik. Pada belajar kognitif, prosesnya mengakibatkan perubahan kemampuan berpikir (cognitive), pada belajar afektif mengakibatkan perubahan dalam aspek kemampuan merasakan (affective) sedang belajar psikomotorik memberikan hasil belajar berupa ketrampilan (psikomotoric). Belajar dilakukan untuk mengusahakan adanya perubahan perilaku pada individu yang belajar. Perubahan perilaku itu merupakan perolehan yang menjadi hasil belajar.Proses pengajaran merupakan sebuah aktivitas sadar untuk membuat siswa belajar. Proses sadar mengandung implikasi bahwa pengajaran merupakan sebuah proses yang direncanakan untuk mencapai tujuan pengajaran. Dalam konteks ini maka hasil belajar merupakan perolehan dari proses belajar siswa sesuai dengan tujuan pengajaran. Tujuan pengajaran menjadi hasil belajar potensial yang akan dicapai oleh anak melalui kegiatan belajarnya.

Nurhadi dan Senduk (2003:59) mengemukakan bahwa salah satu model mengaktifkan siswa dalam belajar adalah dengan menerapkan model pembelajaran kelompok.Karena itu, dalam kegiatan belajar mengajar harus dibentuk kelompok belajar.Model pembelajaran kooperatif memerlukan pendekatan pengajaran melalui penggunaan kelompok kecil dan bekerja sama dalam memaksimalkan kondisi belajar untuk mencapai tujuan belajar (Nurhadi, 2004:112). 
Model pembelajaran kooperatif (Slavin:2008) juga melatih siswa untuk berpartisipasi aktif dan saling berkomunikasi dalam kegiatan diskusi. Model pembelajaran kooperatif terdiri dari beberapa macam, salah satunya adalah metode Student Team Achievement Divisions (STAD).

Dalam upaya mengembangkan potensi siswa secara optimal, diperlukan model pembelajaran yang sistematis dan terarah seperti STAD ini dipilih untuk mengatasi hal-hal yang diuraikan diatas, karena pembelajran kooperatif tipe STAD menciptakan masyarakat belajar.Siswa tidak hanya belajar dari guru tetapi juga belajar dari sesama siswa. Pembelajaran kooperatif model STAD, murid ditempatkan dalam kelompok belajar beranggotakan empat sampai lima orang murid yang merupakan campuran dari kemampuan akademik yang berbeda, sehingga dalam setiap kelompok terdapat murid yang berprestasi tinggi, sedang, dan rendah atau variasi jenis kelamin, kelompok ras dan etnis, atau kelompok social lainnya. Pendapat yang hampir sama juga di kemukakan oleh Khaeruddin (Usman, $2009: 12$ ) bahwa "Dalam STAD, siswa ditempatkan dalam kelompok belajar beranggotakan 4-5 orang yang merupakan campuran menurut tingkat kinerja, jenis kelamin dan suku"

Betitik tolak dari 2 pengertian di atas maka dapat disimpulkan bahwa Model Pembelajaran STAD merupakan salah satu model pembelajaran kooperatif yang terdiri dari 4-5 orang murid yang di bantuk secara heterogen seperti kemampuan akademik yang berbeda, variasi jenis kelamin, ras maupun etnis. Dari hasil penelitian dari 40 siswa hanya 20 orang atau sekitar (52\%) yang memenuhi standar KKM yang telah ditetapkan yaitu 75, dengan ketuntasan belajar yang diharapkan minimal $75 \%$, artinya pembelajaran yang dilakukan belum optimal Berdasarkan hal tersebut maka dianggap penting bagi peneliti untuk mengadakan penelitian melalui penerapan model tipe STAD pada pembelajaran Ekonomi siswa kelas XI MA USB FILIAL Batam Kota. Adapun tujuan penelitian ini adalah untuk (1) Meningkatkan hasil belajar siswa dengan menggunakan model pembelajaran kooperatif tipe STAD pada materi Ekonomi MA USB FIIAL Batam Kota T.P 2018/2019, (2) Meningkatkan aktivitas belajar siswa dengan menggunakan model pembelajaran kooperatif tipe STAD pada materi Ekonomi XI MA USB FILIAL Batam Kota T.P 2018/2019, (3) Meningkatkan psikomotorik siswa dengan menggunkan model pembelajaran kooperatif tipe STAD pada materi Ekonomi XI MA USB FILIAL Batam Kota T.P 2018/2019.

Penelitian ini menggunakan metode pembelajaran STAD. Metode pembelajaran STAD dikembangan oleh Slavin (2008), metode ini merupakan metode pembelajaran yang didasarkan pada teori belajar kognitif. Pendidik hanya berperan sebagai fasilitator dan bukan sebagai pemberi informasi. Guru menciptakan suatu lingkungan yang konduksif, sedangkan siswa harus mampu menemukan dan memecahkan masalahnya sendiri pada proses pembelajaran.

\section{METODE PENELITIAN}

Penelitian ini menggunakan tekhnik Penelitian Tindakan Kelas (PTK). Carr dan Kemmis menyatakan bahwa PTK adalah suatu bentuk refleksi diri yang dilakukan oleh partisipan (guru, siswa, atau kepala sekolah) dalam situasi sosial (termasuk pendidikan) untuk memperbaiki rasionalitas dan kebenaran dari: (a) praktik praktik sosial atau pendidikan yang dilakukan sendiri, (b) pengertian mengenai praktik praktik tersebut, (c) situasi situasi (lembaga-lembaga) tempat praktik praktik tersebut dilaksanakn (Hardjodiputro, 1997). Subjek penelitian ini adalah siswa kelas XI MA USB FILIAL Batam Kota Tahun Pelajaran 2018/2019 dengan jumlah siswa sebanyak 40 siswa yang terdiri dari 22 perempuan dan 18 laki-laki. Penelitian ini dilakukan di MA USB FILIAL Batam Kota. Pada hari senin 8 Maret untuk siklus 1 dan 22 Maret siklus 2 (Semester 2 T.P. 2018/2019) Dengan Kompetensi Dasar : Menggali informasi dari teks laporan informati hasil observasi tentang ilmu ekonomi untuk membantu pemahaman .

Penelitian ini direncanakan sebanyak 2 siklus masing-masing siklus 1 kali pertemuan. Siklus 1 menjelaskan sub konsep tentang ilmu ekonomi sedangkan pada siklus 2 
menjelaskan sumber daya yang ada melalui pilihan - pilihan kegiatan produksi,konsumsi dan distribusi.

\section{Siklus I}

Proses pelaksanaan Penelitian Tindakan Kelas (PTK) pada siklus 1 terdapat 1 kali pertemuan, yakni sebagai berikut :

\section{a. Tahap Perencanaan}

Pada siklus 1 membahas sub konsep ILMU EKONOMI melalui penerapan model kooperatif tipe STAD yang didahului oleh perencanaan yang meliputi :

1. Menyusun Rencana Pelaksanaan Pembelajaran (RPP) tentang sub konsep ILMU EKONOMI melalui penerapan model kooperati tipe STAD

2. RPP yang telah dibuat beserta perangkat pembelajarannya selanjutnya diperbaiki seperlunya dengan mempertimbangkan alokasi waktu yang tersedia.

3. Menyusun soal-soal evaluasi yang akan diujikan secara tertulis kepada siswa pada setiap kali pertemuan

\section{b. Tahap Pelaksanaan Tindakan}

1. Siswa telah diberi tugas membaca bahan ajar (buku paket) di rumah sebelum materi tersebut akan dibahas, maksudnya agar konsep yang dipelajari telah dipahami oleh siswa sehingga diperoleh kesiapan belajar.

2. Siswa di ajak mendiskusikan secara bersama-sama tentang materi yang diajarkan

3. Kegiatan pembelajaran, secara umum dalam kegiatan ini siswa mendapatkan penjelasan materi,diskusi kelompok dengan model kooperatif tipe STAD

c. Observasi dan Evaluasi Tindakan Kegiatan pada tahap ini adalah sebagai berikut :

1. Observasi terhadap pelaksanaan PTK dengan menggunakan lembar observasi aktivitas dan respon siswa serta guru dari modifikasi Borich (1995) dalam Supramono.

2. Peningkatan hasil belajar siswa diperoleh dari tes hasil belajar siswa (post test dan pre test) dan kemampuan siswa dalam memahami pembelajaran. Data ini dijadikan bahan pertimbangan dalam melakukan refleksi pada siklus berikutnya.

\section{d. Tahap Refleksi}

Pada tahap ini dilakukan evaluasi terhadap proses pembelajaran pada siklus 1 dan menjadi pertimbangan untuk memasuki pada siklus 2. Pertimbangan yang dilakukan bilamana dijumpai satu komponen di bawah ini yang belum terpenuhi, yaitu sebagai berikut

a. Siswa mencapai ketuntasan individual $\geq 65 \%$ dan ketuntasan klasikal jika $\geq 85 \%$ dari seluruh siswa mencapai ketuntasan individual yang diambil dari tes hasil belajar (pre test dan post test).

b. Hasil pemahaman terhadap materi cukup baik

\section{Siklus II}

Proses pelaksanaan penelitian tindakan kelas pada siklus 2 ini terdapat 1 kali pertemuan, yakni sebagai berikut :

\section{a. Tahap Perencanaan}

Pada siklus 2 membahas sub konsep ketergantungan antara produsen, konsumen, dan pengurai berdasarkan pemanfaatan lingkungan sekitar sebagai sumber belajar yang didahului oleh perencanaan yang meliputi :

1) Menyusun Rencana Pelaksanaan Pembelajaran (RPP) tentang sub konsep ILMU EKONOMI

2) RPP yang telah dibuat beserta perangkat pembelajarannya selanjutnya diperbaiki seperlunya dengan mempertimbangkan alokasi waktu yang tersedia. 
3) Menyusun soal-soal evaluasi yang akan diujikan secara tertulis kepada siswa pada setiap kali pertemuan.

\section{b. Tahap Pelaksanaan Tindakan}

1. Siswa telah diberi tugas membaca bahan ajar (buku paket) di rumah sebelum materi tersebut akan dibahas, maksudnya agar konsep yang dipelajari telah dipahami oleh siswa sehingga diperoleh kesiapan belajar.

2. Siswa di ajak mendiskusikan secara bersama-sama tentang materi yang diajarkan seperti pada siklus 1

3. Kegiatan pembelajaran, secara umum dalam kegiatan ini siswa mendapatkan penjelasan materi,diskusi kelompok dengan model kooperatif tipe STAD

\section{c. Observasi dan Evaluasi Tindakan}

Kegiatan pada tahap ini adalah sebagai berikut :

1. Observasi terhadap pelaksanaan PTK dengan menggunakan lembar observasi aktivitas dan respon siswa serta guru dari modifikasi Borich (1995) dalam Supramono.

2. Peningkatan hasil belajar siswa diperoleh dari tes hasil belajar siswa (post test dan pre test) dan kemampuan siswa dalam memahami pembelajaran.

\section{d. Tahap Refleksi}

Pada tahap inilah hasil peneitian akan tampak, apakah semua indikator yang dirancang dalam penelitian ini akan berhasil atau tidak.

\section{HASIL DAN PEMBAHASAN}

\section{A. Deskripsi Hasil Penelitian Perbaikan Pembelajaran}

Berdasarkan pelaksanaan perbaikan pembelajaran yang dilakasanakan dengan Langkah-langkah dari mulai kegiatan awal hingga hasil evaluasi, melakukan pengolahan data dengan hasil yang diperoleh sebagai berikut :

Tabel 1. Hasil Observasi Evaluasi Terhadap Siswa Siklus I dan II

\begin{tabular}{|r|l|c|c|}
\hline NO & NAMA SISWA & $\begin{array}{c}\text { SIKLUS 1 } \\
\text { NILAI }\end{array}$ & $\begin{array}{c}\text { SIKLUS II } \\
\text { NILAI }\end{array}$ \\
\hline 1 & Abiyu & 60 & 70 \\
\hline 2 & Agung & 70 & 80 \\
\hline 3 & Al saka & 80 & 90 \\
\hline 4 & Annisa Fitri & 50 & 60 \\
\hline 5 & Arnandho & 70 & 80 \\
\hline 6 & Aurelia & 60 & 70 \\
\hline 7 & Bernike & 50 & 60 \\
\hline 8 & Cahaya & 70 & 80 \\
\hline 9 & Dehza zakira & 60 & 60 \\
\hline 10 & Dezy & 70 & 70 \\
\hline 11 & Diva Aulia & 60 & 80 \\
\hline 12 & El alia & 80 & 70 \\
\hline 13 & Fabian Fadila & 90 & 90 \\
\hline 14 & Fazira Tirsya & 70 & 90 \\
\hline 15 & Hana Salsabila & 60 & 80 \\
\hline 16 & Imanez Desta & 90 & 70 \\
\hline 17 & Jason Devito & 50 & 90 \\
\hline 18 & Juelana Aqni & 60 \\
\hline
\end{tabular}




\begin{tabular}{|r|l|c|c|}
\hline 19 & M.azwan & 50 & 60 \\
\hline 20 & Mahdiyah & 70 & 80 \\
\hline 21 & M.Rizqi & 60 & 70 \\
\hline 22 & M.Farel & 50 & 50 \\
\hline 23 & Andito & 70 & 80 \\
\hline 24 & M.Farhan & 80 & 80 \\
\hline 25 & M.Nur Rifki & 50 & 70 \\
\hline 26 & Mutiara & 90 & 50 \\
\hline 27 & Nadine Alifah & 80 & 90 \\
\hline 28 & Nayla Dwi & 60 & 80 \\
\hline 29 & Noraqidah & 80 & 70 \\
\hline 30 & Nurshakirana & 50 & 90 \\
\hline 31 & Sigit Mulyana & 60 & 50 \\
\hline 32 & Rafi Ibra & 90 & 70 \\
\hline 33 & Rasya Prastio & 80 & 90 \\
\hline 34 & Rifaldo Alisky & 50 & 90 \\
\hline 35 & Satria Abdila & 80 & 70 \\
\hline 36 & Sheila Nika & 60 & 90 \\
\hline 37 & Syahrul Amri & 60 & 80 \\
\hline 38 & Tasya & 90 & 70 \\
\hline 39 & Toriko & 2680 & 70 \\
\hline 40 & Velia Nada & 67 & 90 \\
\hline & & Jumlah & 75 \\
\hline & & Rata-Rata & \\
\hline
\end{tabular}

Tabel 2. Hasil Observasi Evaluasi Terhadap Siswa dari Siklus I dan II

\begin{tabular}{|c|c|c|c|c|c|}
\hline \multirow[b]{2}{*}{ NO } & \multirow[b]{2}{*}{ NILAI } & \multicolumn{2}{|c|}{ SIKLUS 1} & \multicolumn{2}{|c|}{ SIKLUS II } \\
\hline & & $\begin{array}{l}\text { BANYAK } \\
\text { SISWA } \\
\end{array}$ & JUMLAH & $\begin{array}{c}\text { BANYAK } \\
\text { SISWA }\end{array}$ & JUMLAH \\
\hline 1 & 100 & & & & \\
\hline 2 & 90 & 5 & 450 & 10 & 900 \\
\hline 3 & 80 & 7 & 560 & 10 & 800 \\
\hline 4 & 70 & 8 & 560 & 12 & 840 \\
\hline 5 & 60 & 11 & 660 & 5 & 300 \\
\hline 6 & 50 & 9 & 450 & 3 & 150 \\
\hline 7 & 40 & & & & \\
\hline 8 & 30 & & & & \\
\hline 9 & 20 & & & & \\
\hline 10 & 10 & & & & \\
\hline \multirow{2}{*}{\multicolumn{2}{|c|}{$\begin{array}{c}\text { JUMLAH } \\
\text { RATA-RATA }\end{array}$}} & 4 & 2680 & 40 & 2990 \\
\hline & & & 67 & & 74.75 \\
\hline
\end{tabular}


Berdasarkan hasil observasi terhadap siswa dalam evaluasi ilmu ekonomi dari siklus I dan II dapat kita lihat adanya peningkatan nilai rata -rata maupun jumlah siswa yang mendapatkan nilai 60 keatas, dimana pada siklus satu nilai rata-rata siswa masih dibawah 60 .

Dan dari hasil data yang peneliti lakukan terhadap siswa dalam bentuk langsung dalam pembinaan yaitu belajar secara tatap muka di kelas, pembinaan karakternya dan pengetahuan siswa lebih cepat tercapai, karena bagi siswa yang tidak bisa mengakses informasi dari sumber lain bisa bertanya langsung, dan karakter siswa lebih terbentuk. Sedangkan yang tidak langsung yaitu dengan kegiatan berupa pemberian tugas, observasi terhadap lingkungan sekitar siswa, kunjungan ke beberapa instansi terkait dengan pembelajaran dan dengan tutor sebaya, secara tidak langsung telah membantu pembinaan dalam menambah wawasan siswa.

Tabel 3. Persentase Hasil Evaluasi ILMU EKONOMI berdasarkan Kategori Baik, Sedang, dan Kurang pada Siklus I dan II

\begin{tabular}{|c|c|c|c|c|c|}
\hline \multirow{2}{*}{ Kategori } & \multirow{2}{*}{$\begin{array}{c}\text { Rentang } \\
\text { Nilai }\end{array}$} & \multicolumn{2}{|c|}{$\begin{array}{c}\text { SIKLUS I } \\
\text { Sumlah } \\
\text { Siswa }\end{array}$} & $\begin{array}{c}\text { SIKLUS II } \\
\text { Siswa }\end{array}$ & $\%$ \\
\hline Baik & $\mathbf{8 0 , 9 0 , 1 0 0}$ & 12 & 30 & 20 & 50 \\
\hline Sedang & $\mathbf{7 0}$ dan 60 & 19 & 48 & 17 & 43 \\
\hline Kurang & $\begin{array}{l}\mathbf{1 0 , 2 0 , 3 0 , 4 0 ,} \\
\text { dan 50 }\end{array}$ & 9 & 22 & 3 & 7 \\
\hline
\end{tabular}

Berdasarkan tabel presentase hasil observasi terhadap siswa dalam evaluasi ilmu ekonomi berdasarkan kategori baik, sedang dan kurang pada siklus 1 dan siklus 2 terdapat $50 \%$ berkategori baik. Sedangkan yang berkategori sedang sebesar $43 \%$ dan $7 \%$ kategori sedang.

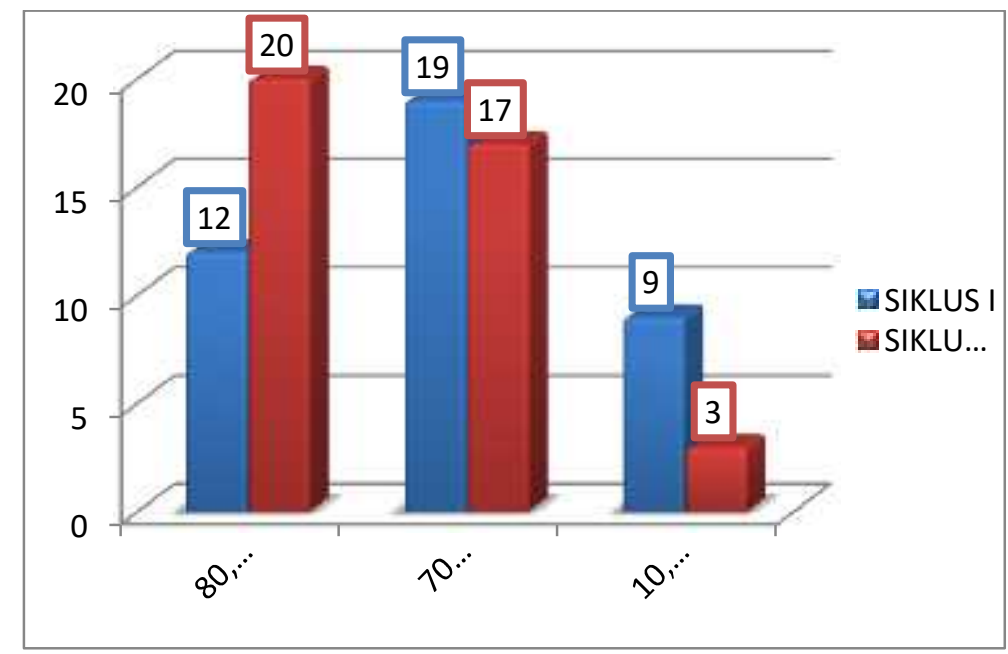

\section{Gambar 1. Pembelajaran Pendidikan Ilmu Ekonomi Siklus I dan I}

Berdasarkan grafik pembelajaran pendidika diatas dapat dijelaskan bahwasanya siswa yang kategori tinggi sebanyak 32 siswa, sedang 36 siswa dan rendah sebanyak 12 siswa 


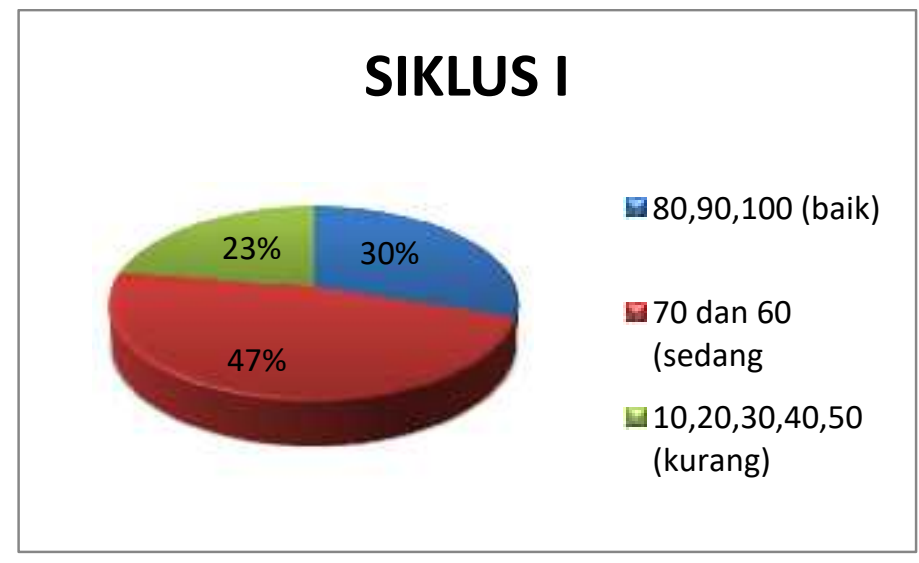

Gambar 2. Persentase Hasil Evaluasi Ilmu Ekonomi Berdasarkan Ketegori Baik, Sedang Dan Kurang Pada Siklus I

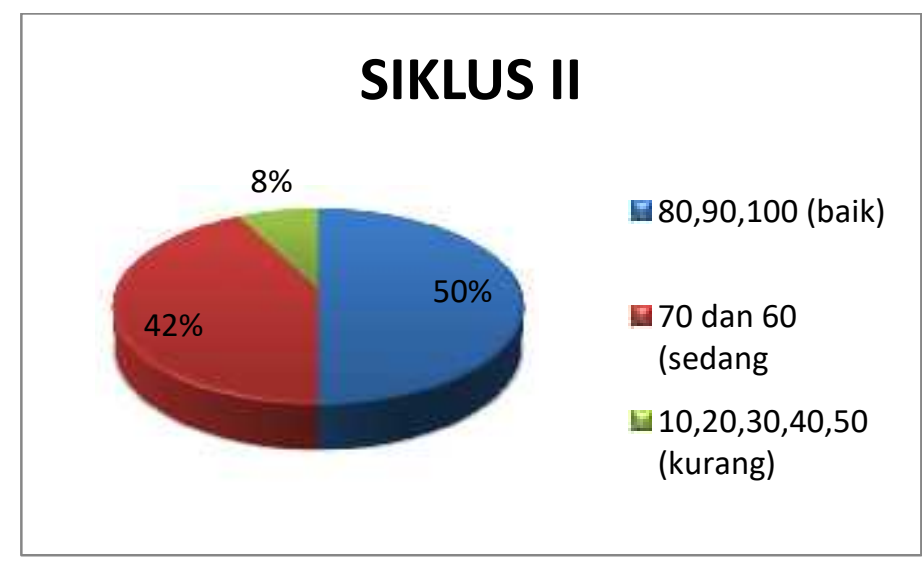

Gambar 3. Persentase Hasil Evaluasi Ilmu Ekonomi Berdasarkan Kategori Baik,

\section{Sedang Dan Kurang Pada Siklus II}

Dengan demikian dapat disimpulkan terjadinya peningkatan antara pembelajaran siklus 1 dan siklus 2. Sehingga dapat disimpulkan bahwasannya Penggunaan model pembelajaran kooperatif pantas dipertimbangkan untuk digunakan guru khusus di XI MA USB FILIAL Batam Kota pada mata pelajaran EKONOMI model pembelajaran kooperatif memeberikan dampak yang positif terhadap peningkatan minat, perhatian serta motivasi belajar siswa.

\section{KESIMPULAN}

Dari hasil perbaikan pembelajaran dapat disimpulkan bahwa untuk meningkatkan minat, perhatian serta motivasi belajar siswa kelas XI MA USB FILIAL BATAM pada mata pelajaran Ekonomi dapat dilakukan antara lain melalui : pemilihan Model Pembelajaran yang bervariasi, penggunaan alat peraga, selalu memberikan motivasi terhadap siswa, memberikan penjelasan materi pembelajaran yang sistematis dan jelas memberikan kesempatan kepada siswa untuk bertanya tentang materi yang belum dipahami, pemberian tugas yang bervariasi, mengambil kesimpulan setelah pembahasan materi.

Penggunaan model pembelajaran kooperatif pantas dipertimbangkan untuk digunakan guru khusus di XI MA USB FILIAL Batam Kota pada mata pelajaran EKONOMI model pembelajaran kooperatif memeberikan dampak yang positif terhadap peningkatan minat, perhatian serta motivasi belajar siswa.

\section{DAFTAR PUSTAKA}

Amri,Sofyan.dkk. (2010). Proses Pembelajaran Kreatif dan Inovatif dalam Kelas. Prestasi.Prestasi.Jakarta. 
Anonim. (2007). Panduan Pengajaran Mikro. Yogyakarta: UPPL - UNY.

Campbell. (1994). Biology.New York: The Benjamin Cummings Publishing Co.Inc.

Departemen Pendidikan Nasional. (2006). Permendiknas Nomor 22 Tahun 2006 Tentang

Standar Isi Standar Isi untuk Satuan Pendidikan Dasar dan Menengah. Jakarta:

Depdiknas

Departemen Pendidikan Nasional. (2006). Permendiknas Nomor 23 Tahun 2006 Tentang

Standar isi Standar Kompetensi Lulusan untuk Satuan Pendidikan Dasar dan

Menengah. Jakarta: Depdiknas.

Hartanto,L.N. (2004) .Biologi Dasar. Yogyakarta : Penebar Swadaya.

Hamalik, Oemar. (2004).Proses Belajar Mengajar.Bumi Aksara

Mukminan. (2003). Pengembangan Silabus Matakuliah Pengajaran Mikro bdan PPL Berdasarkan KBK. Makalah Seminar dan Lokakarya. Yogyakarta: UPPL - UNY.

Nasution, 1992.Didaktik Asas - Asas Mengajar.Bandung : Kaifa.

Nasution, S. (2000). Berbagai Pendekatan dalam Proses Belajar Dan Mengajar. Jakarta:Bumi Aksara

Suryosubroto. (1997). Proses Belajar-Mengajar di Sekolah.Jakarta:Rineka Cipta 